\title{
Financing Problems Faced By The Lebanese SMEs: An Empirical Study
}

Viviane Y. Naïmy, Notre Dame University, Lebanon

\begin{abstract}
During the last two decades, there was unanimity around the importance of the role of Small and Medium Enterprises (SMEs) in the development of economies, of job creation and social stability. This issue concerns industrialized countries as well as developed countries. The purpose of this paper is to study the methods and the financing problems faced by Lebanese SMEs, as well as the behavior of banks in terms of credit allocation. An illustration is presented through a survey covering 56 SMEs: 16 SMEs belonging to the area of Kartaba and 40 SMEs belonging to Beirut suburbs. Moreover, and based on data collected from 30 credit files and on interviews held with important bankers, this paper try to identify the components of the credit assessment process, the risk acceptance criteria, and the categories of loans available for SMEs.
\end{abstract}

\section{Introduction}

During the last two decades, there was unanimity around the importance of the role of Small and Medium Enterprises (SMEs) in the development of economies, of job creation and social stability. This issue concerns industrialized countries as well as emerging countries.

The purpose of this paper is to study the methods and the financing problems faced by Lebanese SMEs, as well as the behavior of banks in terms of credit allocation. The main question is, indeed, to identify to what point the Lebanese financial system is able to fulfill its principal function, that is, to finance the economy in order to improve the growth. The Lebanese productive sector consists of a great number of SMEs, mainly constituted of small firms most of which is of family structure. Small Enterprise constitutes the backbone of the Lebanese economy. $90 \%$ of all industrial companies employ on the whole less than 10 workers ${ }^{1}$. Many factors contributed to the proliferation of SMEs, particularly: the crumbling of the great property, the massive rural migration, the indigenous predisposition for liberal work and for direct and fast profit, the harmful effects of the Lebanese war on the principal aggregates of the economy, and the absence of barriers blocking the entry of competing trades.

The SMEs financing problem is currently worrying the public authorities. The fast change of the international economic environment ${ }^{2}$ is threatening the Lebanese SMEs, mainly because of the major delay SMEs had during the war. However, if SMEs do not act in order to prevent these dangers (and if the public authorities do not intervene in support), the future of the SMEs is on the way to be seriously compromised. The Lebanese economy would then be subjected to major difficulties.

The first part of this paper is devoted to establish a diagnosis of the Lebanese SMEs situation. The description of the theoretical framework appears in the first section. After a quick presentation of characteristics and particularities, we proceed to evaluate the role of the SMEs in the Lebanese economy. The last section of this part is devoted to analyzing the Lebanese SMEs financing means. An illustration is presented through a survey covering 56

1 Industry census of the years 1994-1996.

2 The free trade area, the euro-med agreement, the Arab market, etc. 
SMEs: 16 SMEs belonging to the area of Kartaba ${ }^{3}$ and 40 SMEs belonging to Beirut suburbs. In spite of our limited sample - carried out in diversified branches of industry - this study, nevertheless, enables us to profile a general tendency regarding the present situation of the Lebanese SMEs.

The behavior of Lebanese banks in terms of financing is analyzed in the second part of this study. This part highlights the role of the banking sector in the financing of Lebanese economy. Based on data collected from 30 credit files and on 4 interviews held with important bankers, this part tries to identify the components of the credit assessment process, the risk acceptance criteria, and the categories of loans available for SMEs.

\section{SMEs And Financing Terms}

\subsection{Definition Of SMEs}

There is no universal consensus regarding the definition of SMEs. The APEC ${ }^{4}$ gives many definitions to SMEs. According to this organization, the definition is particular to each country and is a function of the phase of the country's economic development and of the corresponding conditions governing its state.

Several parameters are used to define SMEs, such as: manpower, invested capital, assets value, sales volume, output capacity, and managerial characteristics. Table 1 reflects the parameters used in certain countries for the definition of their SMEs.

\begin{tabular}{|l|l|}
\hline Country & Selected criteria \\
\hline Indonesia & Number of employees, assets value, and sales volume \\
\hline Mexico & Number of employees and sales volume \\
\hline Japan & Number of employees and equity shareholders \\
\hline Brunei & Number of employees \\
\hline Philippines & Number of employees and total assets \\
\hline Thailand & Number of employees and equity shareholders \\
\hline
\end{tabular}

Several countries, particularly, New Zealand and Hong Kong, do not have an official definition of SMEs. Lebanon belongs to this category of countries. In Lebanon, we have only one legislated law ${ }^{5}$ attempting a "definition" of the SMEs. It is the law authorizing the National Institute of Deposits to participate in the capital of the "Institute of Credit Guarantee - Société de Garantie des Crédits - " allocated to SMEs. This law defines the SMEs as being enterprises employing a maximum of 20 employees. Given the inaccuracy of this definition and given the qualitative character of the United Nations proposed definition ${ }^{6}$, we will, in the present analysis, adopt the most commonly used definition in France. This definition ${ }^{7}$ considers three categories of SMEs: handicrafts firms, small firms and medium-size firms. The distinction between one and another is based on the manpower of each category according to the following table:

\begin{tabular}{|l|l|}
\hline Firm & Manpower \\
\hline Handicrafts firms & From 0 to 9 \\
\hline Small firms & From 10 to 49 \\
\hline Medium firms & From 50 to 499 \\
\hline
\end{tabular}

3 A Lebanese village, located in the North of Lebanon.

4 Asia Pacific Economic Committee Co-operation on Trade and Investment (1994). "The APEC survey one small and medium enterprises". The APEC includes 18 countries: Brunei, Australia, Canada, popular China, South Korea, Hong Kong, Indonesia, Japan, Malaysia, Mexico, New Zealand, Papua New Guinea, Philippines, Singapore, Taiwan and Thailand.

5 Law No 24, 02.23.1999, Classeur de la législation libanaise : Monnaies et Banques, volume 25, Al Halabi edition, p.15.

6 UNIDO, United Nations Industrial Development Organization. "Assistance to the Lebanese Small and Medium Enterprises", September 1997, p7.

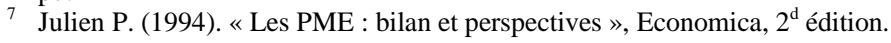




\subsection{General Features of SMEs}

- $\quad$ Family Domination: where the manager and his family control the capital of the firm.

- Management centralization and individual decision ${ }^{8}$ : the centralization of management is the resultant of the capital property concentration.

- Internal growth problem: beyond a certain size, the company stops progressing mainly because of the inefficiency of its management.

- $\quad$ Rudimentary information systems ${ }^{9}$ : internal and external information systems are of an extreme simplicity and are closely related to the leader's personality.

- $\quad$ Financing problems ${ }^{10}$ : the above-mentioned characteristics, particularly, the "size" of the SMEs, strongly influence the finance of these firms. The size constitutes a fundamental criterion generally associated with the economic power of the company and, therefore, with its negotiation capacity. Below is a quick description ${ }^{11}$ of the main financial problems encountered by the SMEs:

- One of the most serious financial consequences of the "size" is the credit rationing or the difficulty related to the credit access at the same cost (interest) granted to large firms. This "cost difference" constitutes "the finance-gap ${ }^{12}$ ".

- The SMEs risk is primarily due to the fact that the bankers have a great difficulty evaluating risks incurred by SMEs ${ }^{13}$. Risks are directly related to the lack of transparency in terms of financial declaration. This situation contributes to increasing the credit fees.

- The rationing of the external resources constitutes another serious financing problem. SMEs are not able to freely issue new shares via the financial markets. This is mainly due to a voluntary blocking on behalf of managers regarding any additional capital increase. This phenomenon is explained by the fear of managers of losing their control.

- The majority of SMEs undergo significant working capital pressures so that the liquidity management remains a priority and a difficult constraint to circumvent.

- Conservation ${ }^{14}$ of the property right: SMEs owners prefer internal financing to external financing, thus holding a greater part of the profit. If necessary, they prefer the bond financing to the capital financing in order to avoid property sharing and, consequently, to avoid the sharing of the decision-making processes with other partners.

\subsection{Role Of The Smes In The Lebanese Economy}

The evaluation of the SMEs role in the national economy requires a direct access to statistics in order to determine their quantitative and qualitative characteristics. However, official statistics and censuses, are becoming a rare commodity in Lebanon ${ }^{15}$. The Trade Register, one of the principal official organizations supposed to provide information on the number of SMEs, is currently in the "reorganization" phase and therefore, is not able to provide these data. Moreover, the classification of these data does not inform about the number of SMEs or about the accurate number of all firms operating in Lebanon. Until now, Lebanon had only three industrial censuses: the first one dates back to 1970 , the second one was held in $1985^{16}$, and the third in 1994/95. The last census was carried out under the auspices of the General Direction of Industry with the technical and financial assistance of Germany via the German Agency for Technical Assistance.

8 Keasy K., Waltson R., (1993). «Small firm management: ownership, finance and performance». Blackwell Business.

9 O'Farell P., Hitchens D., (1989). "Small firm competitiveness and Performance" Gill and Macmillan.

${ }^{10}$ Beedles W. (1992). « Small firm equity cost » Journal of Small Business Management, July, p.54-64.

${ }^{11}$ Roberts M., Stevenson H., (1991). « Alternative sources of financing ». The entrepreneurial venture, Harvard Business School publications.

12 This difference is constituted of two gaps: (1) the knowledge gap that is the insufficiency of knowledge and competence of the SMEs' leaders, and (2) the supply gap illustrated through a quantitative credit rationing intended for SMEs.

${ }_{13}$ Midland Bank Report (1992). "The changing financial requirements of smaller companies". Midland Bank Business Economic Unit.

${ }^{14}$ Brouke A., (1993). «Sources of finance for the fast growth firm », Research papers in Banking and Finance, School of Accounting, Banking and Economics. IEF edition, Institute of European Finance, University College of North Wales.

15 In addition, the majority of the files of the State were destroyed during the war and the access to the safeguarded part is made difficult because of the non-computerization of data: data remained on paper and is not classified by order or updated.

16 This census is partial. 


\subsubsection{Number}

According to the aforementioned census ${ }^{17}$, the number of the production units in Lebanon is about 22,107 units, all sectors considered.

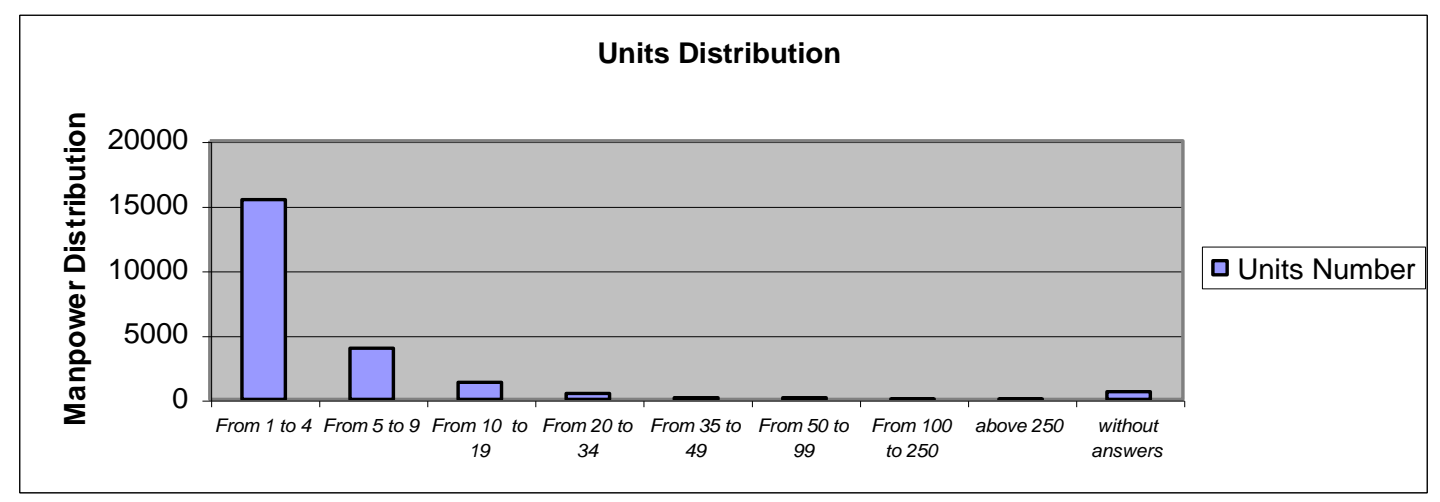

\subsubsection{Size}

The application of the French definition to Lebanese SMEs, shows that SMEs are primarily handicrafts and small firms. Thus the census states that $87.9 \%$ of firms are handicrafts industries employing between 1 and 9 employees. Small firms, employing between 10 and 49 employees, constitute only $8.6 \%$ of the total units. Lastly, the manpower in average firms employing between 50 and 499 employees does not exceed $0.9 \%$.

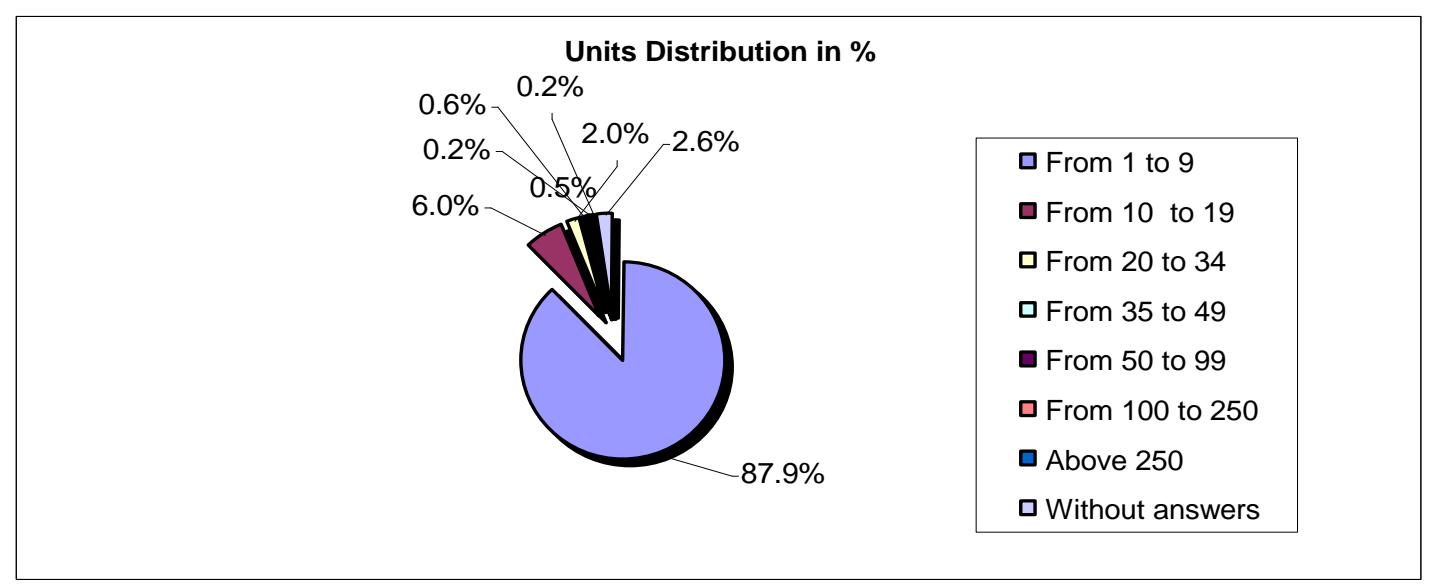

\subsubsection{Labor Market}

Total industrial firms employs $144,177^{18}$ workers. However, the handicrafts firms employ 79,707 workers, that is, $55.28 \%$ of the whole SMEs labor force. This percentage becomes $21.7 \%$ for the small firms and $20.2 \%$ for the medium-sized firms.

\footnotetext{
${ }^{17}$ United Nations Industrial Development Organization, UNIDO (1997). “Assistance to the Lebanese small and medium enterprises". Programming mission report, September 1997.

18 This figure does not include the seasonal workers.
} 


\section{Manpower Distribution (in\%), by firms type}

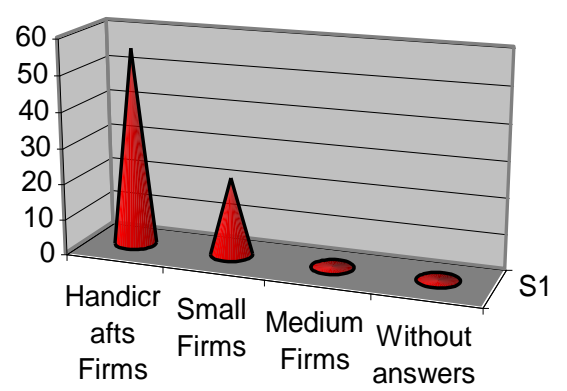

\subsubsection{Sales Turnover}

Total turnover of the Lebanese SMEs is evaluated at USD 3,719 million. While the handicrafts firms represent $87.9 \%$ of the total units and employ $55.3 \%$ of the whole industry labor force, they carry out $37 \%$ of the sector total turnover. Small and medium-size firms carry out $29.3 \%$ and $31 \%$ respectively of this total.

\subsubsection{Value Added}

Total value added is about USD 1,822 million. The value added created by handicrafts firms constitutes $40.3 \%$ of the added value generated by the whole sector, the remainder being divided into $28.2 \%$ for small firms and $28.9 \%$ for medium-size firms. Consequently, the value added generated by one employee is about 9,200 dollars in the handicrafts firms. Total value added constitutes $49 \%$ of their sales turnover. Lastly, it should be noted that industries employing less than 5 workers have a better ratio value added /turnover. This ratio is equivalent to $56.8 \%$.

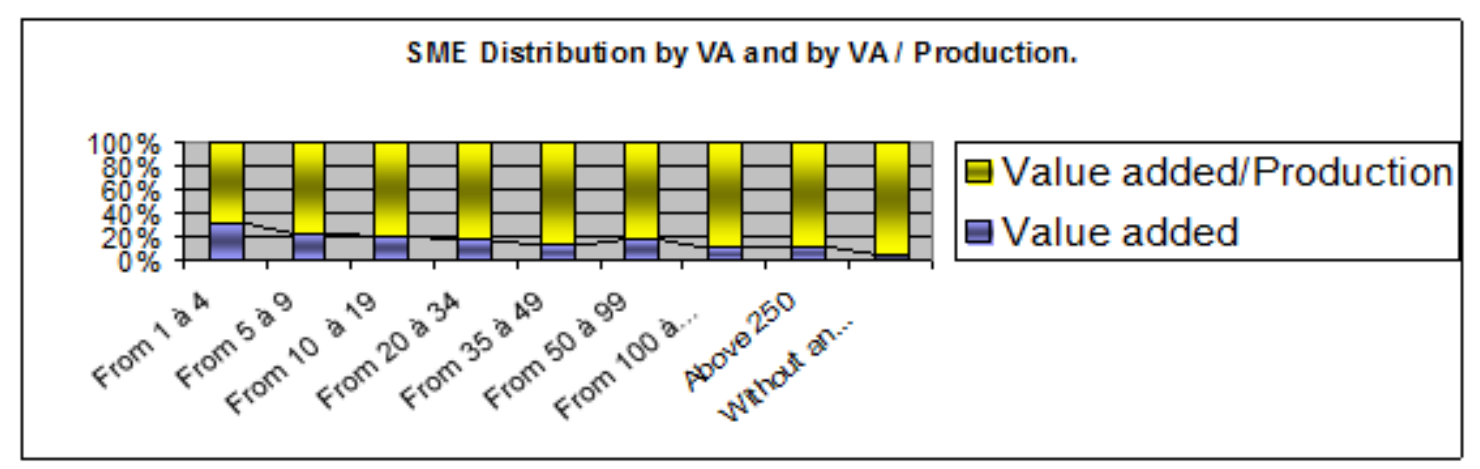

\subsection{Financing Problems Faced By The Lebanese Smes: An Empirical Study}

\subsubsection{Objectives And Methodology}

The ground investigation that we carried out, has triple objectives:

1. To bring out the financing means of the Lebanese SMEs (fixed assets investment and working capital).

2. To define the problems related to the credits access.

3. To determine the position of borrowers with regard to financing issues 
The instrument used for this purpose consists of a questionnaire that includes:

- Information request about the company

- 10 direct questions ${ }^{19}$

\subsubsection{Selection Of The Sample}

Beirut ${ }^{20}$ Sample: The sample used in Beirut consists of 40 companies belonging to various activity sectors and employing between 2 and 20 workers. The sample is based on the following structure: 4 construction firms, 7 computers serving companies, 4 fast-food industries, 10 handicrafts firms, 3 bookshops, 3 paper mills, 3 trade printing companies, 5 design studios, and 1 shopping center.

Kartaba Sample: The sample covers 16 SMEs located in Kartaba. The sample mainly concentrates on handicrafts firms: hairdressers, bakeries, butchers, small shops, and gasoline stations.

Limitations of the sample: Conscious of the condensed volume of our sample and of the partial diversification of the population in terms of firms number, geographical distribution etc., we, nevertheless, estimate that this investigation provides an acceptable radiography of the situation; tendencies and prospects. In fact, we have focused this investigation on the financing problems faced by the Lebanese SMEs. Taking into consideration quantified information, such as turnover, debt ratios, profit etc., may not have been consistent.

\subsubsection{Results}

\section{$\underline{\text { Beirut Results }}$}

The low equity shareholders prevent SMEs from any financing prospect for substantial investments. Indeed, no questioned SME referred to equity shareholders financing mean on the short run, while only $2.5 \%$ of the companies raised their capital in order to carry out minor investments.

The bank loan represents a modest source of real financing to SMEs. Only $17.5 \%^{21}$ have access to this financing mean against mortgages and guarantees required

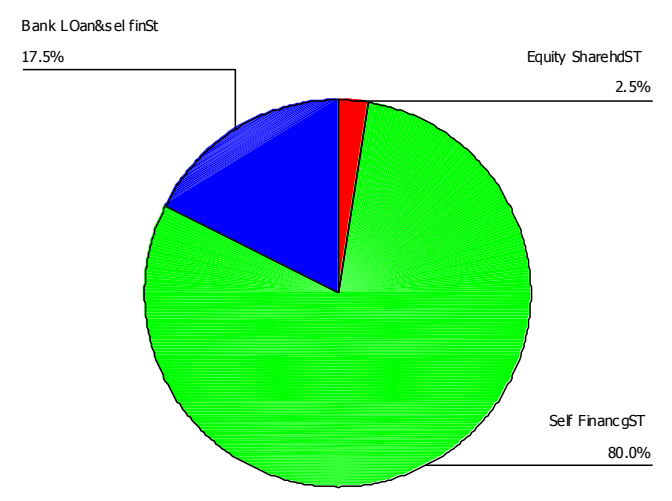
by the Lebanese financial institutions. Bank loans are always conceived for short run. In extreme cases, bank loans take the form of medium term credit particularly when they are renewed. The renewal of short-term loan (overdraft) represents also a common practice within the Lebanese commercial banks.

\footnotetext{
${ }^{19}$ Please refer to appendix 1. We have personally carried out this questionnaire. Questions that seemed to be somewhat too specialized were simplified to the extent of popularization. As an example, we put question 8 in the following way: "Which financing mean appears to you the most adapted to your company: banks or Stock Exchange?" We have also revised the investigation part related to question 10.

${ }^{20}$ The covered regions are: Jdeideh, Zalka, Jal-el Dib, Dikwaneh, Dora, Fanar, and Ain Saadeh. 21
}

Financing Means

\begin{tabular}{|ll|r|r|r|r|}
\hline & & & & Cumulative \\
& & Frequency & Percent & Valid Percent & Percent \\
\hline Valid & Equity SharehdST & 1 & 2.5 & 2.5 & 2.5 \\
& Self FinancgST & 32 & 80.0 & 80.0 & 82.5 \\
& Bank LOan\&sel finSt & 7 & 17.5 & 17.5 & 100.0 \\
& Total & 40 & 100.0 & 100.0 & \\
\hline
\end{tabular}




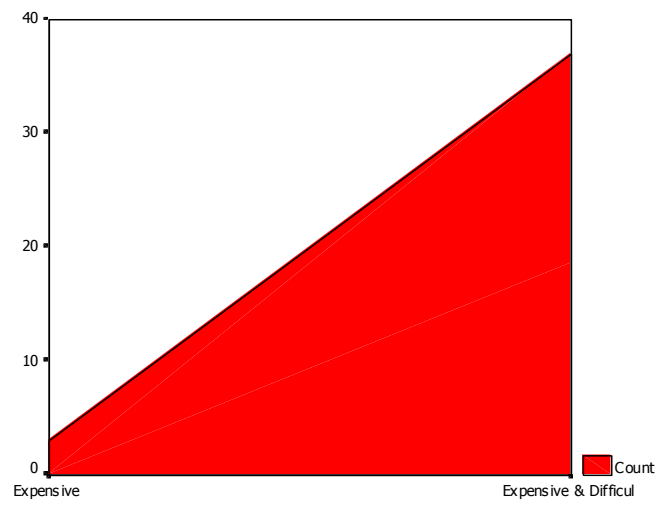

Access to Bk Loan

Consequently, self-financing seems to be the main source of financing for the short and medium terms, since $90 \%{ }^{22}$ of the questioned SMEs had a systematic recourse to this mean. However, some companies were obliged to use loan sharks ${ }^{23}$ in order to ensure the fund contributions. The financing of the Lebanese SMEs via the stock market is nonexistent. Indeed, when SMEs directors were asked if they are ready to open their capital to the public, their answers remained conservatives: $91 \%{ }^{24}$ of those who accept to go public, insist on keeping their decision-making power perfectly intact. Informal loans are not commonly used: only $2 \%$ of SMEs have recourse to such a financing mean.

The recourse to the bank loan is asserted by only $17 \%$ of the questioned SMEs: which is in conformity with the results of the first question. In fact, $100 \%$ of the questioned firms consider that the access to the bank loan is at the same time difficult and expensive. Consequently, companies that had access to bank loans were obliged to yield to the banking institutions requirements. The absence of personal guarantees represents the major obstacle to the access of $92 \%$ of the SMEs to bank loans. SME managers who succeed to get a bank loan classify their relationship with their banker as very traditional ${ }^{26}$,

\footnotetext{
${ }^{22}$ According to the above frequencies distribution, the percentage is $80 \%$, but we have to add $10 \%$ of SMEs using both means: banks and self financing.

${ }^{23}$ Such operations are prohibited by the law when interest rates exceed a certain ceiling.

${ }^{24} 91.6 \%=11 / 12$, where 12 SMEs accepted the idea of going public and only one SME was ready to decentralize the decision-making process
}

Go Public

\begin{tabular}{|c|c|c|c|c|c|}
\hline & & Frequency & Percent & V alid Percent & $\begin{array}{l}\text { Cumulative } \\
\text { Percent }\end{array}$ \\
\hline \multirow[t]{4}{*}{ Valid } & Yes 10 to $25 \%$ & 11 & 27.5 & 27.5 & 27.5 \\
\hline & Yes 50 to $75 \%$ & 1 & 2.5 & 2.5 & 30.0 \\
\hline & No & 28 & 70.0 & 70.0 & 100.0 \\
\hline & Total & 40 & 100.0 & 100.0 & \\
\hline
\end{tabular}

${ }^{25}$ It should be noted that this result differs from that of the first question. This fact confirms the presence of a margin of error inherent to this type ${ }_{26}$ s surveys. However, this error margin remains reduced and acceptable.

\section{Bank Loan * Relation with Bker Crosstabulation}

Count

\begin{tabular}{|c|c|c|}
\hline & $\begin{array}{c}\text { Relation with } \\
\text { Bker }\end{array}$ & \multirow[b]{2}{*}{ Total } \\
\hline & Conventional & \\
\hline $\begin{array}{l}\text { Bank Loan Yes } \\
\text { Total }\end{array}$ & $\begin{array}{l}7 \\
7\end{array}$ & $\begin{array}{l}7 \\
7\end{array}$ \\
\hline
\end{tabular}

\section{Case Processing Summary}

\begin{tabular}{|c|c|c|c|c|c|c|}
\hline & \multicolumn{6}{|c|}{ Cases } \\
\hline & \multicolumn{2}{|c|}{ Valid } & \multicolumn{2}{|c|}{ Missing } & \multicolumn{2}{|c|}{ Total } \\
\hline & $\mathrm{N}$ & Percent & $\mathrm{N}$ & Percent & $\mathrm{N}$ & Percent \\
\hline $\begin{array}{l}\text { Bank Loan * } \\
\text { Relation with Bker }\end{array}$ & 7 & $17.5 \%$ & 33 & $82.5 \%$ & 40 & $100.0 \%$ \\
\hline
\end{tabular}

It's worth mentioning that missing data corresponds to SMEs that have no recourse to the bank loan. 
undoubtedly far from any prospect of a comprehensive relationship. $90 \%{ }^{27}$ of the companies choose the indirect loan. $91.6 \%$ of them prefer the long-term fund. Only $10 \%$ choose the long-term direct ${ }^{28}$ financing mean.

Moreover, $98 \%$ of the questioned managers declared that they are ready to pay an insurance premium (up to $2 \%$ of the required amount) to a credit insurance company that may facilitate the bank loan access.

All SME managers aspired to a reduction of interest rates that may facilitate their financial transactions. Consequently, this requires an increase (injection) of the money supply in the economy, thus, avoiding the crowding-out effects. SMEs managers advanced this claim unanimously.

\section{$\underline{\text { Kartaba Results: }}$}

The most flagrant result observed within the questioned SMEs at Kartaba is the complete absence of any financial culture. SME managers were not able to distinguish between equity shareholders and self-financing. Moreover, the concept of long or short-term financial means seems to them very ambiguous. However, we were able to trace out the following results:

$100 \%$ of the SMEs depend on their self-financing to carry out their investment. Bank loan represents a purely inaccessible financing source. Kartaba SMEs have no idea about the stock market or the concept of opening up the capital to the public. 3\% hope to get a bank loan to expand their business. All of them are ready to pay an extra insurance premium if this would facilitate getting additional funds. Finally, Kartaba SME managers were unanimously blaming and criticizing the government macroeconomic policies in terms of interest rates and price levels, infrastructure, taxes, etc.

\subsubsection{Conclusion}

This investigation highlights a serious problem of financing faced by the Lebanese SMEs. Granting a credit requires, often, the satisfaction of almost impossible conditions to be fulfilled by these firms. In addition, the constraints blocking the development ${ }^{29}$ of the stock exchange market draw aside any direct financing prospect for these firms. Furthermore, the macroeconomic policy applied in Lebanon during the last decade - having resorted to a very strong public debt - is responsible for a heavy crowding-out effect. This has resulted in high interest rates unfavorable for any potential productive investment. The whole situation is being accompanied by an obvious lack of financial culture felt by managers and decision makers.

\section{Financing Of SMEs: Banking Sectors And Other Financing Institutions}

The object of this second part consists in identifying the possible methods of financing being offered to the Lebanese SMEs and the selection criteria according to which credits are allocated.

27

Financing Tools

\begin{tabular}{|ll|r|r|r|r|}
\hline & & & & \multicolumn{1}{c|}{$\begin{array}{c}\text { Cumulative } \\
\text { Percent }\end{array}$} \\
\hline Valid & Intermediate Loan ST & 3 & 7.5 & 7.5 & 7.5 \\
& Intermediate Loan M\&LT & 33 & 82.5 & 82.5 & 90.0 \\
& Direct Loan M\&LT & 4 & 10.0 & 10.0 & 100.0 \\
Total & 40 & 100.0 & 100.0 & \\
\hline
\end{tabular}

${ }^{28}$ Again, a second error margin is observed in comparison with the results of the second question.

${ }^{29}$ Such as the very high liquidity risk, the lack of transparency, the absence of institutional dealers, the weakness of financial instruments supply etc. 
For this purpose, we had:

- 4 interviews held with bankers (decision makers) and managers belonging to the top four Lebanese banks ${ }^{30}$.

- Data from 30 credit files $^{31}$

- 10 business loan inquiries

\subsection{Importance Of The Banking Sector}

The Lebanese financial system is a bank-oriented system. Firms are strongly dependent on bank loans, which represent their main financing mean. Big corporations, SMEs and the Government, call exclusively on the banking sector to face their financing needs. Commercial banks are mainly refinanced by the Central Bank. Interest rates adjustments via the supply and the demand of fund, is completely absent. This market is still embryonic. The credit market is a "suppliers market" where commercial banks constitute an "oligopoly". This dominance of commercial banks in the mobilization of saving can be analyzed according to the importance of deposits in the structure of the banking resources, or according to the prevalence of the bank deposits in the components of the money supply ${ }^{32}$.

\subsection{Research Findings In Brief}

Based on the 10 business inquiries, results can be summarized as follows:

1. $70 \%{ }^{33}$ of clients (basically SMEs) are not satisfied with the banks' credit policy because of:
a. The insufficient financing amounts
b. The Pricing of the loan
c. The level of collateral
d. The relationship with managers

2. Only $30 \%$ of clients were found to be satisfied.

3. Most businesses cannot accept the thought that bankers require to monitor and examine the company's daily activities

4. Most loan applications are not supported by any business plan, financial budget and forecast, or by a financial analysis.

With respect to the data collected from credit files, we have detected the following results:

1. Commercial banks are in the business of allocating low risk financing ${ }^{34}$.

2. The foremost banks' consideration is centered on the ability of the firm to repay its loan.

3. Collateral securities are considered as a secondary source of payment. Despite the existence of collateral securities, commercial banks seldom recover their total lending amount. Moreover, banks consider that realizing collateral securities or disposing of assets, doesn't belong to the bank business; hence, calling a loan is rather a difficult process.

4. Personal guarantee is a typical requirement in $90 \%$ of the studied cases.

Based on the data collected from the $\mathbf{3 0}$ credit files and according to the 4 interviews held with bankers, we succeeded to determine the components of the credit assessment process, the risk acceptance criteria, and the categories of loans available for SMEs.

\footnotetext{
${ }^{30}$ Société Générale de Banque, Bank of Beirut, Fransabank, and Banque Libano-Française.

${ }^{31}$ The author of this paper personally analyzed those files.

${ }^{32}$ Naïmy V. (2001). "Marchés Emergents, financement des PME et croissance économiques: Etude du cas libanais », Ph.D. dissertation in Economics, Université de Paris XI.

${ }^{33}$ Considered as a very high ratio.

${ }^{34}$ And that for the safety of depositors, for avoiding bad debts and their repercussion on the bank profitability.
} 


\section{Credit Assessment Process}

The credit process is made up of 6 steps:

1. Investigation: the banker starts collecting information from internal and external sources. This step is important in determining the orientation of the second step (first visit).

2. First visit: during the first visit, the banker is able to do a physical inspection of premises, to listen to the owner/financial manager's needs and problems, to get an idea about the know-how and the character of the owner/decision maker, and finally to require the necessary information for the constitution of the credit file.

3. Documentation analysis: documentation is usually divided into the legal ${ }^{35}$, financial ${ }^{36}$, marketing ${ }^{37}$, and general documentation ${ }^{38}$.

4. Negotiation and second visit: during this step, terms and conditions are proposed, and points of views are exchanged.

5. Credit package and approval/rejection: based on the above steps, the banker finalizes the credit analysis and presents his recommendation.

6. Loan and security agreement: in case of a positive recommendation, the bank requires a set of collaterals ${ }^{39}$.

\section{$\underline{\text { Risk Acceptance Criteria }}$}

In general, the risk acceptance criteria are classified under the general, financial, and security criteria.

General criteria: The credit analyst is interested in the management depth and the business continuity of the firm. Moreover, a minimum experience of 3 years in the market is required. Strong credit examination on sponsors, operators and on contractors is frequently done.

Financial criteria: Financial criteria deal with the historical profitability trends (gross and profit margin, etc.), with the financial structure ${ }^{40}$ of the firm, with its repayment capacity ${ }^{41}$, and with its turnover ${ }^{42}$ ratio trends.

Security criteria: Security criteria are a function of personal guarantees, tangible securities and other possible securities.

\section{Categories Of Loans Available For SMEs}

Among the set of loans categories available for SMEs, the most common types are:

Revolving loans: Revolving loans are allocated to support commercial operations and/or short-term needs of SMEs. They are tied to the level of receivables and inventories. The rule of thumb regarding revolving loans consists of computing the revolving loan amount in such a way that the maximum need should level out the sum of $60 \%$ of receivables and $50 \%$ of inventories ${ }^{43}$. If utilization is higher than the rule of thumb overdraft will be used to finance capital expenditures, withdrawals, losses, and under capitalization.

Term loans: The purpose of term loans is to finance the acquisition of long-term assets or capital expenditures. Usually term loans ${ }^{44}$ matches the life of the acquired assets and have a grace period varying between 1 and 2 years.

\footnotetext{
${ }^{35}$ Where indebtedness rights and legal problems are taken into consideration.

${ }^{36}$ Financial documents consist of balance sheet, income statement, cash-flow, budget, etc. The banker requires at least 4 years record to detect financial trends and tendencies of the firm.

${ }^{37}$ Identifying channels of distribution, suppliers base, terms and conditions of collection and payment, competition structure, product advantage, and internal and external success factors, are a must to facilitate the credit decision of the banker.

${ }^{38}$ Such as the CDR (Centrale des Risques), insurance coverage, fixed assets valuation, etc.

${ }^{39}$ Personal guarantees, mortgages, pledge, etc.

${ }^{40}$ For example liquidity ratio trends (W.C > 1.1), leverage ratio trends (debt to equity $<1.5$ or 2 ), receivables to STD ratio, etc.

${ }^{41}$ Cash coverage ratio $>1.3$, debt service ratio $>1.2$

${ }^{42}$ Receivables collection, payment cycle, inventory turnover, etc.

${ }^{43}$ Moreover, banks control on a monthly basis the ratio of receivables and inventories to overdrafts.

${ }^{44}$ Term loans draw out are subject to an availability period and are linked to the work progress and purchase order payments.
} 
Prepayments are not allowed and are subject to penalty fees. Repayments ${ }^{45}$ are made on a quarterly or semi annual basis. Finally, term loans are linked to meeting covenant requirements such as: minimum equity amount, minimum working capital ratio $(>1.1)$, ceiling for the debt to equity ratio ${ }^{46}$, minimum cash coverage ratio $(>1.3)$, and minimum debt service ratio $(>1.2)$.

\subsection{Conclusion}

In Lebanon, the morality of the contractor and the notoriety of the company are regarded as being determining criteria in the decision of the credit allocation. Classified by order of importance, these criteria arise as follows:

1. Morality of the owners and the shareholders and the notoriety of the company.

2. Equity shareholders ${ }^{47}$ of the company: the debt ratio should not exceed $50 \%$

3. Medium and long-term credits: those should not exceed 4 years of the self-financing capacity of the company in question.

4. Funds for cash flow movement: those must generally account for $25 \%$ of the sales turnover.

5. Respect of liquidity ratios: the working capital must finance the requirements in working capital up to a total value of $70 \%$.

\section{Conclusions}

\section{Accumulation Of Structural And Economic Problems Behind The Lebanese SMEs Weakness}

The performance of the Lebanese SMEs according to the results of this investigation, is weak. Problems of a structural nature as well as obstacles related to the economic situation have been emphasized.

\subsection{Structural problems}

Maladjustment of the Lebanese SMEs cultures ${ }^{48}$ to the managerial and financial requirements have been detected in light of our study: particularly deadlocked mentalities already proven in former contexts. The disastrous macroeconomic and financial situation of the last decade, reflect the latent failure of these stereotyped behaviors.

SMEs culture must be capable of adaptation. Influences exerted by the environment changes oblige SMEs to adjust. SMEs culture is, in fact, what makes the personality of the company. The corporate identity is the outside image of the company. The cultural identity is a major component of the SME identity. The cultural ${ }^{49}$ potential combined with the potential in know-how and financial means, determine the total identity of the firm.

Some prerequisites are necessary for the establishment of an SMEs culture in Lebanon. Leaders of SMEs must be sensitive to the cultural dimension. For that reason, leaders and employees need to be trained. The culture of the firm therefore, is effectively integrated within each strategy. The development of the SME culture must be carried by executives and employees. There is no prototype culture universally valid. Each culture must be examined according to the strategy taken by the firm. Lebanese SMEs have to develop their own business culture. Each culture is singular in itself; it takes time and requires consistent perseverance.

\footnotetext{
${ }^{45}$ Repayments include capital and interest payments.

${ }^{46}$ For both capital and non-capital intensive projects.

${ }^{47}$ Their volume reassures the banker even if the activity of the company is not indeed predominating. In any event, financial means of the associates constitutes an important criterion for the decision-making.

${ }^{48}$ For more details and definitions regarding SMEs culture you can refer to Kobi J.M., et Wuthrich H. (1991), "Culture d'entreprise, modes d'actions", éditions Nathan.

49 The cultural potential is made up of cultural symptoms such as the personality of the leaders, the ritual and symbols existing in the company, the style of communication, the system of value initiating the strategy, the types of structures and procedures, the systems of management and the reaction to economic, social, technological and ecological influences.
} 


\subsection{Economic Problems}

The structural problems explain only partially the results of this investigation. Indeed, when the managerial choices are being in conformity with the principles postulated in this investigation, macroeconomic reality takes on the responsibility of non-performance:

1. Hard financing, even almost inaccessible, resulting from many legal and institutional blockings handicap the expansion programs of SMEs and make expensive any bank loan. Undeniably, these financial constraints represent an obstacle against SMEs performance.

2. Macroeconomic policies (fiscal and monetary policies) have resulted in the rationing of the bank credits and in an unceasingly negative growth since 1993.

This situation is certainly unproductive in stimulating the performance of the Lebanese SMEs.

\section{References}

1. Asia Pacific Economic Committee Co-operation on Trade and Investment (1994). The APEC survey on small and medium enterprises.

2. Beedles W. (1992). "Small firm equity cost", Journal of Small Business Management, July, p.54-64.

3. Brouke A., (1993). "Sources of finance for the fast growth firm", Research papers in Banking and Finance, School of Accounting, Banking and Economics. IEF edition, Institute of European Finance, University College of North Wales.

4. Classeur de la législation libanaise: Monnaies et Banques, volume 25, Al Halabi edition, p.15, Law No 24, 02.23.1999.

5. Julien P. (1994). "Les PME: bilan et perspectives", Economica, 2d édition.

6. Keasy K., Waltson R., (1993). Small firm management: ownership, finance and performance. Blackwell Business.

7. $\quad$ Kobi J.M., et Wuthrich H. (1991), Culture d'entreprise, modes d'actions, éditions Nathan.

8. Midland Bank Report (1992). "The changing financial requirements of smaller companies". Midland Bank Business Economic Unit.

9. Naïmy V. (2003). "Marchés Emergents, financement des PME et croissance Economiques: Etude du cas libanais", NDU Press.

10. O'Farell P., Hitchens D., (1989). Small firm competitiveness and Performance. Gill and Macmillan.

11. Roberts M., Stevenson H., (1991). "Alternative sources of financing". The entrepreneurial venture, Harvard Business School publications.

12. United Nations Industrial Development Organization, UNIDO (1997). "Assistance to the Lebanese small and medium enterprises". Programming mission report, September 1997. 